Violence and the City in the Modern Middle East 



\section{Violence and the City in the Modern Middle East}

Edited by Nelida Fuccaro 
Stanford University Press

Stanford, California

(C)2016 by the Board of Trustees of the Leland Stanford Junior University. All rights reserved.

No part of this book may be reproduced or transmitted in any form or by any means, electronic or mechanical, including photocopying and recording, or in any information storage or retrieval system without the prior written permission of Stanford University Press.

Printed in the United States of America on acid-free, archival-quality paper

Library of Congress Cataloging-in-Publication Data

Violence and the city in the modern Middle East / edited by Nelida Fuccaro.

pages $\mathrm{cm}$

Includes bibliographical references and index.

ISBN 978-0-8047-9584-5 (cloth : alk. paper) — ISBN 978-0-8047-9752-8 (pbk. : alk. paper) ISBN 978-0-8047-9776-4 (electronic)

1. Urban violence-Middle East-History. 2. Political violence-Middle East-History.

3. City and town life-Middle East-History. I. Fuccaro, Nelida, editor. HN656.Z9V589 2016

$303.60956-\mathrm{dc} 23$

2015021950

Typeset by Bruce Lundquist in 10/14 Minion 